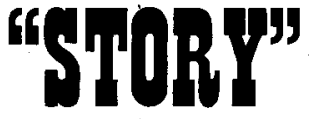

IN POLITICS

biv

\author{
MICHAEL NOVAK
}

"The American bias suggests that modern nations have moved from a worldview composed of myth, story, and symbol to a worldview composed of empirical reason, fact and verificationfrom myth to reality. So deep is the bias of demythologizing that Americans fail to notice how problematic is their own relationship to nature, to one another, to other peoples. ..."

\section{Is Gradualism Dead?}

REFLECTIONS ON ORDER, CHANGE AND FORGE

by

\section{DENIS GOULET}

Ethics \& Foreign Policy Series
"In my view, unless the ground rules of production and decision-making are profoundiy altered within the United States, a world order of authentic development has no chance to be born. Thus, at the very least, a major cultural revolution is needed in the United States. . .."

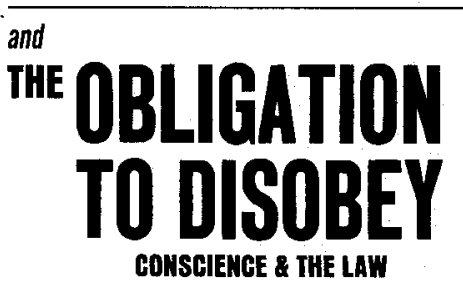

by

\title{
MULFORD Q. SIBLEY
}

\begin{abstract}
"A society which aspires to freedom and 'democracy.' as John Stuart Mill argued, needs citizen's who actively and conscientiously obey rather than those who acquiesce passively or with reluctance. Passive acquiescence or slavish obedience cannot advance either the cause of norl-violence or that of democracy. Possible civil disobedience is the price we must pay if we are to develop the ideal of active rather than tamely passive citizenship. , . ."
\end{abstract}

To: CRIA 170 E. 64th St, New York, N. Y. 10021

Please send me:

$\square$ IS GRADUALISM DEAD? (.50)

$\square$ THE OBLIGATION TO DISOBEY

$\square$ "STORY" IN POLITICS (1.75)
Name.

Address

City. State Zip 
V

1

4

.

4

A

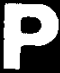

R
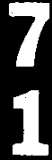